\title{
圆 \\ Factors Influencing the Processed Pineapple Export Competitiveness of Thailand
}

\author{
Thanet Wattanakul ${ }^{1}$ Sakkarin Nonthapot ${ }^{2}$ and Tanawat Watchalaanun ${ }^{3}$
}

\begin{abstract}
This study aims to explore the factors influence the competitiveness of Thailand's processed pineapple exports as well as the impact size of these factors by focusing on canned pineapple (HS 200820) and pineapple juice (HS 200949). This study also determine the competitiveness and market share effects for both products in each market in each Thailand major partner countries. The average price of processed pineapple, GDP per capita and exchange rate were the explanatory variables. The panel data from 2013 to 2017 of 10 partners were used in a panel regression model with pooled OLS, fixed effect and random effect models. The empirical results show that the fixed effect model is the most suitable and that price significantly negatively affected the market share of both products. Moreover, there is a positive effect from GDP per capita on market share for pineapple and the exchange rate positively affected market share for canned pineapple. In addition, Thailand's pineapple juice market share is less price sensitive than the canned pineapple market. The stable and competitive price are necessary conditions to enhance sustainable export competitiveness under current intense competition. The implementation of effective exchange rate management to prevent massive fluctuation is a crucial supporting mechanism to achieve this target. Moreover, the appropriate devaluation is other essential policy to enhance sustainable price competition under the tension competitive environment leads to accelerate the continue market shares in important markets. ${ }^{4}$
\end{abstract}

JEL classification: F13, F14, F15

Keywords: Processed Pineapple, Pineapple Juice, Canned Pineapple, Market Share, Export Competitiveness

\footnotetext{
${ }^{1}$ Indo-China International Trade and Economic Research Sector, School of Economics, Faculty of Interdisciplinary, Khon Kaen University, Nong Khai Campus, Thailand. E-mail: thanet@kku.ac.th

${ }^{2}$ Indo-China International Trade and Economic Research Sector, School of Economics, Faculty of Interdisciplinary, Khon Kaen University, Nong Khai Campus, Thailand

${ }^{3}$ Indo-China International Trade and Economic Research Sector, School of Economics, Faculty of Interdisciplinary, Khon Kaen University, Nong Khai Campus, Thailand.

${ }^{4}$ Acknowledgements

This paper was supported by the Indo-China International Trade and Economic Research Sector, School of Economics, Faculty of Integrated Social Sciences, Khon Kaen University, Nong Khai Campus.
} 


\section{Introduction}

Processed foods have become an important part of many people's lives, such as canned food, fruit juice, bread, bacon, cereal and milk. Furthermore, businesses continually try to improve the taste, shelf-life and nutritional value. In addition, there are now fewer barriers to entry in export markets particularly for developing countries. Consequently, it is very interesting to examine the level of competition of the industry for both imports and exports.

Pineapple is one of the most popular agricultural goods and can be processed and distributed to all parts of the world. The pineapple originates from South America. The plant was spread to other regions in South America by native Brazilians and Paraguayans before being taken to the Caribbean, Central America and Mexico by the Mayans and Aztecs. In 1493, Columbus brought it to Spain (Suzanne Raga, 2015). Additionally, pineapple is an essential ingredient of many foods. The increasing demand for pineapple in some countries is more than domestic production. As a result, many countries import this product from others to satisfy domestic demand. Fresh pineapple can be produced in various convenient forms for export with a long shelf-life, including canned and processed fruit as well as juice.

Thailand was the biggest exporter of canned pineapple and juice in the world market with 46.76 percent market share in canned pineapple and 36.50 percent share of the world market for pineapple juice in 2013. However, the market share of Thailand has since significantly dropped. Between 2013 and 2017, the market share for canned pineapple dropped by around 12.94 percent overall and was dramatically down in Italy and Japan, which dropped by about 30 percent. In the pineapple juice market, $6.48 \%$ of the market share was lost overall and in the Russian market, it dramatically decreased by 20.61 percent (Table 1). This situation indicates that Thailand lost some of its market share to competitors.

Table 1 Market share for Thai exports of canned pineapple and juice with Thailand's top 10 partners

\begin{tabular}{llllllll}
\hline \multicolumn{2}{l}{ Thailand's Market share for canned pineapple } & \multicolumn{3}{l}{ Thailand's Market share for Pineapple juice } \\
\hline Partners & $\mathbf{2 0 1 3}$ & $\mathbf{2 0 1 7}$ & Difference & Partner & $\mathbf{2 0 1 3}$ & $\mathbf{2 0 1 7}$ & Difference \\
\hline Netherlands & $41.94 \%$ & $31.96 \%$ & $-9.99 \%$ & USA & 48.25 & 42.88 & -5.37 \\
USA & $47.95 \%$ & $37.98 \%$ & $-9.97 \%$ & Germany & 50.82 & 54.68 & 3.86 \\
Australia & $82.91 \%$ & $60.19 \%$ & $-22.72 \%$ & Russia & 85.48 & 64.87 & -20.61 \\
Iran & $71.72 \%$ & $63.85 \%$ & $-7.88 \%$ & China & 50.86 & 37.66 & -13.20 \\
Italy & $49.40 \%$ & $16.98 \%$ & $-32.41 \%$ & Japan & 56.29 & 43.59 & -12.70 \\
Spain & $27.24 \%$ & $32.10 \%$ & $4.86 \%$ & Canada & 75.79 & 64.72 & -11.08 \\
Korea & $39.07 \%$ & $24.21 \%$ & $-14.86 \%$ & Iran & 92.10 & 99.34 & 7.23 \\
Japan & $54.80 \%$ & $23.63 \%$ & $-31.17 \%$ & Netherlands & 43.07 & 38.50 & -4.56 \\
UK & $26.32 \%$ & $14.96 \%$ & $-11.35 \%$ & UK & 49.22 & 42.52 & -6.70
\end{tabular}


Wattanakul, Nonthapot \& Watchalaanun | Factors Influencing Processed Pineapple Export

\begin{tabular}{llllllll} 
Taiwan & $15.30 \%$ & $21.36 \%$ & $6.07 \%$ & Spain & 28.56 & 26.83 & -1.73 \\
\hline Average & & $-12.94 \%$ & Average & & -6.48 \\
\hline
\end{tabular}

Source: Trade Map (2019)

Competitiveness can be measured by employing the constant market share model (CMS model) or the RCA concept and others, which focus on the volume of trade value. However, there are a few studies which focus on the change in market share, which is likely to be explained by the demand side. This was the focus of Benkovskin and Wörz (2018), who applied the demand concept to analyze the market share in G7 and BRIC countries. It was found that non-price factors such as taste and quality affected the import behavior of partners and had a greater effect on market share than the relative price factor.

Overall, import value was explained by the degree of openness, the market size, the exchange rate, income (GDP per capita), gross capital formation, and external debt in a positive direction (Khiyavi, Moghaddasi and Yazdani, 2013 , ÖZTÜRK, 2012 and Mansi, 2016). The pineapple market was negatively affected by export price for canned pineapple exports and positively affected by real GDP and population in the case of Indonesia (Wiranthi, Puspi, Mubarok and Faizul, 2017). Study of other important processed agricultural goods export of Thailand such as smoked rubber sheet used different techniques of simultaneous equation with paned data can be obtained. This study investigated the effect of market share and exports of Thailand's rubber smoked sheet to 10 partners between 2008 and 2017 by using panel data, simultaneous equation and three stage least technique (Wattanakul, Nonthapot and Watchalaanun, 2019). It can be affirmed that market share has obviously higher effect on import of partners than market expansion. On the other hand, the exchange rate has considerably strong negative effect on market share of partners. As a result, the efficient macroeconomic both monetary and fiscal policies support by related international trade policies should be implemented to assure better allocation of benefits from trade.

This study aims to analyze the factors influencing export competitiveness for processed pineapple including canned pineapple and pineapple juice from Thailand, including estimates using panel regression in the period 2013 to 2017.

\section{Research Methodology}

This study separates the model estimation into two markets: the canned pineapple market and the pineapple juice market. The competitiveness of Thailand's exports in both markets is determined by the market share of Thailand's export in each market. The influential factors are the average price of each good exported to partner countries, the per capita GDP of partners and the exchange rate (partner currency per Thai baht).

The market share for each product is calculated by comparing the import quantity (tons) of Thai products and the total quantity of imports (tons) in the world market, which were obtained from the Trade Map (2019). Average prices (USD per ton) were also collected from the Trade Map Database (2019). Per capita GDP in US dollars at constant prices (2010) and exchange rate figures 
for each partner country were collected from the World Bank (2019). All of the collected data on Thailand's 10 most important partners were panel data from 2013 to 2017. The canned pineapple market partners comprise the United States of America, Germany, the Russian Federation, China, Japan, Canada, the Islamic Republic of Iran, the United Kingdom and Spain. The main pineapple juice importers comprise the Netherlands, the United States of America, Australia, the Islamic Republic of Iran, Italy, Spain, the Republic of Korea, Japan, the United Kingdom and Taiwan.

Both markets were estimated by using panel regression models including the Pool OLS regression model, the fixed effect least square dummy variable model (FE-LSDF) and the random effect model (REM). These estimation models consider the model optimization by employing the Hausman test. The pool OLS Regression model estimates panel data by simple progress with ordinary least square (OLS) and ignores the individual effect and time effect, which may disturb the error term. The model is probably biased if there are both effects in the estimation results. The model estimation is more appropriate than other models. The estimated model can be written as the following equation:

$$
S_{i j}=\beta_{i j}+\beta_{1 i j} P_{i j}+\beta_{2 i j} G D P_{i j}+\beta_{3 i j} E x_{i j}+\mu_{i j}
$$

When $S_{i j}$ is the market share of Thailand in each market in i country and $\mathrm{j}$ time, $P_{i j}$ is the average price of each export product to $\mathrm{i}$ country and $\mathrm{j}$ time, $G D P_{i j}$ is the GDP per capita of $\mathrm{i}$ country and $\mathrm{j}$ time and $E x_{i j}$ is the exchange rate for i country currency per Thai Baht currency in $\mathrm{j}$ time. $\beta_{i j}$ to $\beta_{3 i j}$ are the parameters, and $\mu_{i j}$ is the error term.

There are many suitable methods that can be applied to solve the problem of the pool OLS regression model. The solution has to be able to remove the disturbance effect error term. The cross-section data must be individual intercepts to fix this problem. The fixed effect of individual can be deployed by incorporating appropriate dummy variables. This concept is known as the fixed effect least square dummy variable (LSDV). The estimated model can be shown as the following equation:

$$
S_{i j}=\beta_{1 i j}+\beta_{2 i j} P_{i j}+\beta_{3 i} G D P_{i j}+\beta_{4 i j} E x_{i j}+\sum_{k=1}^{n} \alpha_{k i j} D_{k i j}+\mu_{i j}
$$

When $\sum_{k=1}^{n} \alpha_{k i j} D_{k i j}$ the individual effect of each partner, and $\mathrm{n}$ is is the number of partners. $D_{k i j}=1$ if $\mathrm{i}=\mathrm{k}$ and $D_{k i j}=0$ if $\mathrm{i} \neq \mathrm{k}$.

Furthermore, the concept is used to explain the difference in intercept effect, which can be a random variable. Therefore, the disturbances of the random variable on the error term are also random. As a consequence, these disturbances can be included in the estimated model without estimation bias by using OLS. This concept is known as the Random Effect model. However, the individual possibly affects other independent variables, which be a cause of error inconsistency. As a result, the individual characteristics of the concept must be considered. The estimated model can be presented as the following equations:

$$
S_{i j}=\beta_{1 i j}+\beta_{2 i j} P_{i j}+\beta_{3 i j} G D P_{i j}+\beta_{4 i j} E x_{i j}+w_{i j}
$$

and $\quad w_{i j}=\mu_{i j}+\varepsilon_{\mathrm{ij}}$ 
Wattanakul, Nonthapot \& Watchalaanun | Factors Influencing Processed Pineapple Export

When $w_{i j}$ is the error term, $\mu_{i j}$ is the $S_{i j}$-specific random effect and $\varepsilon_{\mathrm{ij}}$ is the individual specific random effect. If $\varepsilon_{\mathrm{ij}}$ is random, the random effect model is optimized.

The Hausman test is very widely employed for hypothesis testing and can be applied to test the relationship between the error term in the Random Effect model $\left(w_{i j}\right)$ and the independent variable and time invariant. The null hypothesis is that there is no relationship between $w_{i j}$ and the independent variable or time invariant. The alternative hypothesis is that there is a relationship between them. The Random Effect model is optimal if the null hypothesis is accepted. The Fixed Effect model is chosen if the hypothesis is rejected.

\section{Model Estimation Results and Discussion}

From the empirical results, there are significantly negative directional effects of average price on market share in the Pool OLS model, the fixed effect model and the random effect model. Moreover, in the Fixed Effect model, per capita GDP and exchange rate have a significantly positive effect on market share. On the other hand, there is no significant effect from both factors on the market share in the Pool OLS model and the Random Effect model. The Hausman test result can be used to reject the null hypothesis, thus the Fixed Effect model is optimal (Table 2).

Table 2 Canned pineapple market share model estimation results

\begin{tabular}{|c|c|c|c|}
\hline \multirow{2}{*}{$\begin{array}{l}\text { Independent } \\
\text { Variable }\end{array}$} & \multicolumn{3}{|l|}{ Co-efficient } \\
\hline & Pool OSL & Fixed Effect & Random Effect \\
\hline \multirow{2}{*}{$\mathbf{P}$} & -0.0810 & -0.0324 & -0.0232 \\
\hline & $-5.0204 * * *$ & $-3.6285^{* * *}$ & $-3.3725 * * *$ \\
\hline \multirow{2}{*}{ GDP } & -0.0002 & 0.0023 & -0.0003 \\
\hline & -1.0602 & $2.1517 * *$ & -1.1816 \\
\hline \multirow{2}{*}{$\mathbf{E x}$} & 0.1861 & 0.7787 & 0.1714 \\
\hline & 0.9367 & $1.8798^{*}$ & 0.6545 \\
\hline \multirow{2}{*}{ Intercept } & 148.8936 & -8.8722 & 86.3454 \\
\hline & $8.8782 * * *$ & -0.2500 & $7.5449 * * *$ \\
\hline \multicolumn{4}{|c|}{ Diagnostic Statistics } \\
\hline $\mathbf{R}^{2}$ & 0.4601 & 0.9574 & 0.2356 \\
\hline Adjusted $R^{2}$ & 0.4248 & 0.9435 & 0.1857 \\
\hline F-stat & $13.0648 * * *$ & $69.2257 * * *$ & $4.7258 * * *$ \\
\hline DW stat & 0.3832 & 2.0058 & 1.2549 \\
\hline
\end{tabular}

\section{Hausman test}


Source: From the model estimation results

Notes: $1 . *$ has $90 \%$ level of significance.

2. $* *$ has $95 \%$ level of significance.

3. *** has $99 \%$ level of significance.

There is a significant negative directional effect of the average price on market share for pineapple juice in the Fixed Effect model and the random effect model. Moreover, per capita GDP has an effect on market share in a negative direction in the fixed effect model. The Hausman test result rejects the null hypothesis, thus the Fixed Effect model is optimal (Table 3).

Table 3 Pineapple juice market share model estimation results

\begin{tabular}{|c|c|c|c|}
\hline \multirow{2}{*}{$\begin{array}{l}\text { Independent } \\
\text { Variable }\end{array}$} & \multicolumn{3}{|l|}{ Co-efficient } \\
\hline & Pool OSL & Fixed Effect & Random Effect \\
\hline \multirow{2}{*}{$\mathbf{P}$} & -0.004290 & -0.005328 & -0.006977 \\
\hline & -1.019566 & $-2.457507 * *$ & $-3.505489 * * *$ \\
\hline \multirow{2}{*}{ GDP } & 0.000213 & -0.003316 & -0.000110 \\
\hline & 1.260358 & $-2.702458 * *$ & -0.287429 \\
\hline \multirow{2}{*}{$\mathbf{E x}$} & -0.020056 & -0.470823 & 0.022284 \\
\hline & -0.113657 & -0.755274 & 0.063823 \\
\hline \multirow{2}{*}{ Intercept } & 39.21133 & 185.9515 & 55.01209 \\
\hline & $3.650650 * * *$ & $3.569914 * * *$ & $3.218530 * * *$ \\
\hline \multicolumn{4}{|c|}{ Diagnostic Statistics } \\
\hline$\overline{\mathbf{R}^{2}}$ & 0.054186 & 0.871512 & 0.213096 \\
\hline Adjusted R ${ }^{2}$ & -0.007498 & 0.829840 & 0.161777 \\
\hline F-stat & 0.878447 & $20.91364 * * *$ & $4.152321 * * *$ \\
\hline DW stat & 0.336498 & 2.401442 & 1.917400 \\
\hline \multicolumn{4}{|l|}{ Hausman test } \\
\hline Chi-Sq. Statistic & & $8.014093 * *$ & \\
\hline
\end{tabular}

Source: From the model estimation results

Notes: $1 . *$ has $90 \%$ level of significance.

2. $* *$ has $95 \%$ level of significance.

3. *** has $99 \%$ level of significance. 
Wattanakul, Nonthapot \& Watchalaanun | Factors Influencing Processed Pineapple Export

The model estimation results confirm to basic demand theory. The effect of price on increasing the quantity of imports by partner countries and the link to the market share is a result of increasing per capita GDP, which represents increasing income. The devaluation of the Baht would increase the quantity of imports by partners, which is supported by ÖZTÜRK. M (2012) and Wiranthi, Puspi \& Mubarok, Faizul. (2017). However, the effect of rising per capita GDP on market share for pineapple juice can be negative for Thai exports as the increasing income of partners may lead to more choice and changes in buying behavior. Furthermore, Thailand's pineapple juice market share is less price sensitive than the canned pineapple market.

\section{Conclusion}

It can be confirmed that the important factors that affect Thailand's pineapple market share in both markets are average price, which has a negative effect. Rising per capita GDP has a positive effect in the canned pineapple market and a negative effect in the pineapple juice market. The exchange rate has a positive effect on market share in only the pineapple juice market. Therefore, a stable and competitive price, which is affected by the exchange rate are crucial in enhancing the sustainable competitiveness of processed pineapple from Thailand not only for the major partners but also in the world market. Thai products have become more expensive in these markets because the Pound, Euro, Dollar, Yuan and other currencies have fallen against the strong baht. This makes them less competitive and reduces demand.

\section{Acknowledgements}

This paper was supported by the Indo-China International Trade and Economic Research Sector, School of Economics, Faculty of Integrated Social Sciences, Khon Kaen University, Nong Khai Campus. The funding of this research was supported by Research and Graduate Studies, Khon Kaen University.

\section{References}

Baltagi, B. H. (2008). Econometric Analysis of Panel Data, 4th ed. New York: John Wiley \& Sons.

Greene, W.H., (2011). Econometric Analysis, 7th ed., Prentice Hall.

Hausman, J. A. (1978). Specification Tests in Econometrics, Econometrica, 46, 1251-1272.

Khiyavi K., Moghaddasi. R and Yazdani. S., (2013). Investigation of Factors Affecting the International Trade of Agricultural Products in Developing Countries. Life Science Journal 2013; 10(3s)

Konstantins Benkovskin and Julia Wörz. (2018). What drives the market share changes? Price versus non-price factor. Structural Change and Economic Dynamics 45(2018); 9-29. 
Lotfali Aghili, Unes Salmani and Mir Abdullah Hosseini. (2017). Factors Affecting Market Share of Iranian Hand-woven Carpet in Singapore. International Journal of Economics and Financial Issues, 2017, 7(1), 500-505.

Mansi, N. (2016). Analysis of Factors Influencing Import Demand in Nigeria. International Journal of Arts Humanities and Social Sciences, 1(5), 1-5. Retrieved from www.ijahss.com

Mustafa ÖZTÜRK. (2012). Macroeconomic factors affecting the import in turkey. Journal of QafQaz University.

Raga, Suzanne. (2015). The Super Luxe History of Pineapples. Retrieved 9 January 2019 from http://mentalfloss.com/article/65506/super-luxe-history-pineapples-and-why-they-usedcost-8000

Trade map. (2019). List of export for the selected product (Product: 200820 Pineapples, prepared or preserved, whether or not containing added sugar or other sweetening matter or spirit (excluding preserved with sugar but not laid in syrup, jams, fruit jellies, marmalades, fruit purée and pastes, obtained by cooking)). Retrieved 15 January 2019 from https://www.trademap.org/Country_SelProduct_TS.aspx?nvpm $=1 \% 7 \mathrm{c} \% 7 \mathrm{c} \% 7 \mathrm{c} \% 7 \mathrm{c} \% 7 \mathrm{c}$ $200820 \% 7 \mathrm{c} \% 7 \mathrm{c} \% 7 \mathrm{c} 6 \% 7 \mathrm{c} 1 \% 7 \mathrm{c} 1 \% 7 \mathrm{c} 2 \% 7 \mathrm{c} 2 \% 7 \mathrm{c} 1 \% 7 \mathrm{c} 2 \% 7 \mathrm{c} 1 \% 7 \mathrm{c} 1$

Trade map. (2019). List of export for the selected product (Product: 200949 Fruit juices, incl. grape must, and vegetable juices, unfermented, not containing added spirit, whether or not containing added sugar or other sweetening matter). Retrieved 15 January 2019 from https://www.trademap.org/Country_SelProduct_TS.aspx?nvpm $=1 \% 7 \mathrm{c} \% 7 \mathrm{c} \% 7 \mathrm{c} \% 7 \mathrm{c} \% 7 \mathrm{c}$ $2009 \% 7 \mathrm{c} \% 7 \mathrm{c} \% 7 \mathrm{c} 4 \% 7 \mathrm{c} 1 \% 7 \mathrm{c} 1 \% 7 \mathrm{c} 2 \% 7 \mathrm{c} 2 \% 7 \mathrm{c} 1 \% 7 \mathrm{c} 2 \% 7 \mathrm{c} 1 \% 7 \mathrm{c} 1$

Trade map. (2019). List of import for the selected product (Product: 200820 Pineapples, prepared or preserved, whether or not containing added sugar or other sweetening matter or spirit (excluding preserved with sugar but not laid in syrup, jams, fruit jellies, marmalades, fruit purée and pastes, obtained by cooking). Retrieved 15 January 2019 from https://www.trademap.org/Country_SelProduct_TS.aspx?nvpm $=1 \% 7 \mathrm{c} \% 7 \mathrm{c} \% 7 \mathrm{c} \% 7 \mathrm{c} \% 7 \mathrm{c}$ $200820 \% 7 \mathrm{c} \% 7 \mathrm{c} \% 7 \mathrm{c} 6 \% 7 \mathrm{c} 1 \% 7 \mathrm{c} 1 \% 7 \mathrm{c} 1 \% 7 \mathrm{c} 2 \% 7 \mathrm{c} 1 \% 7 \mathrm{c} 2 \% 7 \mathrm{c} 1 \% 7 \mathrm{c}$

Trade map. (2019). List of import for the selected product (Product: 200949 Fruit juices, incl. grape must, and vegetable juices, unfermented, not containing added spirit, whether or not containing added sugar or other sweetening matter). Retrieved 15 January 2019 from https://www.trademap.org/Country_SelProduct_TS.aspx?nvpm $=1 \% 7 \mathrm{c} \% 7 \mathrm{c} \% 7 \mathrm{c} \% 7 \mathrm{c} \% 7 \mathrm{c}$ $2009 \% 7 \mathrm{c} \% 7 \mathrm{c} \% 7 \mathrm{c} 4 \% 7 \mathrm{c} 1 \% 7 \mathrm{c} 1 \% 7 \mathrm{c} 1 \% 7 \mathrm{c} 2 \% 7 \mathrm{c} 1 \% 7 \mathrm{c} 2 \% 7 \mathrm{c} 1 \% 7 \mathrm{c} 1$

Wattanakul and Watchalaanun (2017). The Relationship between Foreign Direct Investment from Thailand and Export on the Economic Growth of Laos, Australasian Accounting, Business and Finance (AABFJ), Vol. 11, Issue. 3 (2017), pp. 55-66. 
Wattanakul, Nonthapot \& Watchalaanun | Factors Influencing Processed Pineapple Export

Wattanakul, Nonthapot and Watchalaanun (2019). An Analysis of the Competitiveness and Market Expansion of Thailand's Rubber Smoked Sheet Exports - A Technical Note, Australasian Accounting, Business and Finance (AABFJ), Vol. 13, Issue. 4 (2019), pp. $92-$ 99.

Wiranthi, Puspi, Mubarok and Faizul. (2017). Competitiveness and the Factors Affecting Export of the Indonesia Canned Pineapple in the World and the Destination Countries. KnE Life Sciences. 2. 339. 10.18502/kls.v2i6.1056. 